\title{
Socio-demographic differentiation of selected risk factors in a group of patients with respiratory system diseases
}

\section{Społeczno-demograficzne zróżnicowanie wybranych czynników ryzyka u pacjentów z chorobami układu oddechowego}

\author{
Agnieszka B. Bartoszek¹, Katarzyna H. Kockaํ, Justyna Dejneka², Barbara Ślusarska1, Marcin Rząca \\ 'Department of Family Medicine and Community Nursing, Chair of Oncology and Environmental Health, Faculty of Health Science, \\ Medical University of Lublin, Lublin, Poland \\ Head of the Department: Barbara Ślusarska MD, PhD \\ ${ }^{2}$ Team Support Centers, Lublin, Poland \\ Head of the Center: Maria Pawela MSc \\ ${ }^{3}$ Department of Oncology, Chair of Oncology and Environmental Health, Faculty of Health Science, Medical University of Lublin, \\ Lublin, Poland \\ Head of the Department: Prof. MU Andrzej Stanisławek MD, PhD
}

Key words: risk factors, socio-demographic factors, respiratory system diseases.

Słowa kluczowe: czynniki ryzyka, czynniki społeczno-demograficzne, choroby układu oddechowego.

\begin{abstract}
Introduction: Tobacco smoking is the major risk factor of respiratory system diseases. However, it is worth noticing other crucial factors increasing the risk of such diseases, such as alcohol consumption, obesity, excess fat tissue around the neck and throat, malnutrition, tranquilisers and soporifics, and previous respiratory system diseases.

Aim of the research: To analyse the socio-demographic differentiation of selected respiratory system diseases risk factors in a group of pulmonological patients.

Material and methods: The research covered 126 pulmonological patients with chronic obstructive pulmonary disease (COPD), tuberculosis, or lung cancer. The study employed standardised research tools: the Fagerström test, Mini Nutritional Assessment (MNA), and a self-designed questionnaire. Neck circumference and body weight measurements were performed to calculate body mass index and waist-hip ratio. The significance level was established at $p<0.05$.

Results: Most patients smoked tobacco in the past or were active smokers. Over 50\% reported occasional alcohol drinking and demonstrated malnutrition risk or abdominal obesity. Smoking was more often practised by men, people with lower education, and COPD and tuberculosis patients. Malnutrition risk was associated with tuberculosis and lung cancer. Tobacco consumption as a respiratory system diseases risk factor more often applied to men and people below 50 years of age. The use of soporifics increased with age and concerned lung cancer patients. Previous respiratory system diseases correlated with the respondents' education.

Conclusions: The most frequent respiratory system diseases risk factors are smoking, malnutrition, and abdominal obesity. Respiratory system diseases risk factors are significantly correlated with sex, age, place of residence, and previous respiratory system diseases.
\end{abstract}

\section{Streszczenie}

Wprowadzenie: Najczęstszym czynnikiem ryzyka wystąpienia chorób układu oddechowego jest palenie tytoniu. Należy jednak zwrócić uwagę na inne istotne czynniki zwiększające ryzyko zachorowania, takie jak spożywanie alkoholu, otyłość, nadmiar tkanki tłuszczowej umieszczonej wokół szyi i gardła, niedożywienie, przyjmowanie leków uspokajających i nasennych oraz przebyte choroby układu oddechowego.

Cel pracy: Analiza społeczno-demograficznego zróżnicowania wybranych czynników ryzyka rozwoju chorób układu oddechowego u pacjentów oddziałów pulmonologicznych.

Materiał i metody: W badaniu wzięło udział 126 pacjentów oddziałów pulmonologicznych z rozpoznaniem przewlekłej obturacyjnej choroby płuc (POChP), gruźlicy i raka płuc. W pracy zastosowano następujące standaryzowane narzędzia badawcze: test Fagerströma, Kwestionariusz oceny stopnia odżywienia (MNA) oraz autorski kwestionariusz w formie ankiety. Dokonano pomiarów obwodu szyi, wzrostu i masy ciała do oceny wskaźnika masy ciała i WHR (stosunek obwodu talii do obwodu bioder). Za poziom istotności różnic przyjęto $p<0,05$. 
Wyniki: Większość pacjentów w przeszłości paliła papierosy lub obecnie jest czynnymi palaczami tytoniu. Ponad połowa chorych przyznaje się do okazjonalnego picia alkoholu, jest zagrożonych niedożywieniem i ma otyłość brzuszną. Palenie tytoniu częściej dotyczy mężczyzn, osób z niższym wykształceniem, cierpiących na POChP i gruźlicę. Zagrożenie niedożywieniem związane jest z gruźlicą i rakiem płuc. Spożycie alkoholu jako czynnik ryzyka wystąpienia chorób układu oddechowego częściej stwierdza się u mężczyzn i osób poniżej 50. roku życia. Przyjmowanie leków nasennych wzrasta z wiekiem i dotyczy pacjentów z rakiem płuc. Przebyta choroba układu oddechowego koreluje z wykształceniem respondentów.

Wnioski. Najczęstszymi czynnikami ryzyka wystąpienia chorób układu oddechowego są palenie papierosów, zagrożenie niedożywieniem oraz otyłość brzuszna. Czynniki ryzyka rozwoju chorób układu oddechowego są istotnie związane z płcią, wiekiem, miejscem zamieszkania i przebytą chorobą układu oddechowego.

\section{Introduction}

Currently, respiratory system diseases, after circulatory system diseases and cancer, are one of the major causes of death in the world, and the increase of their incidence is usually related to lifestyle [1].

The most common risk factor of respiratory system diseases is tobacco smoking, which is regarded as a major public health issue [2]. According to the NATPOL 2011 report, the percentage of tobacco smokers in Poland is 27\% [3]. Another risk factor is the consumption of alcohol, which contributes to obstructive pulmonary diseases because it blocks inhalation neurons and increases muscle weakness, and also is an evident risk factor of tuberculosis, raising the respiratory system's susceptibility to infections [4-6]. Obesity can also be a primary cause of respiratory disease and can have a negative influence on the breathing mechanics and the course of separate respiratory system diseases. It may lead to respiratory disorders occurring during sleep: obstructive sleep apnoea and respiratory failure associated with obesity [7]. Obstructive sleep apnoea is also associated with excessive fat tissue around the neck and throat (when the neck circumference is more than $43 \mathrm{~cm}$ among men and $41 \mathrm{~cm}$ among women) [8]. Sleep-associated respiratory disorders accompanied by obesity (mainly abdominal) can lead to respiratory failure. The respiratory system diseases that occurred, especially pneumonia or asthma, in childhood, connected with later smoking, can be a chronic obstructive pulmonary disease (COPD) risk factor [9]. In turn, malnutrition is a risk factor of tuberculosis [5] and early deaths caused by respiratory issues [10].

\section{Aim of the research}

The objective was to analyse the socio-demographic differentiation of selected respiratory system disease risk factors in a group of pulmonological patients.

\section{Material and methods}

The research covered 126 pulmonology ward patients in the Mazowieckie Province (the Mazovian Centre for the Treatment of Lung Diseases and Tuberculosis in Otwock) and the Lubelskie Province (Independent Public Clinical Hospital No. 4 in Lublin) between February and April 2014. The management of the mentioned healthcare institutions consented to the research procedure. Purposive sampling was applied. The criteria of selecting patients for the research was diagnosed COPD, lung cancer, or tuberculosis. Participation in the research was voluntary and anonymous, according to the guidelines of the Declaration of Helsinki. The following standardised research tools were used for the purposes of the study: the Fagerström Test for Nicotine Dependence and the Mini Nutritional Assessment (MNA). In the Fagerström test the nicotine dependence level can be low, medium, or high. Results from 6 to 10 points are interpreted as a high dependence level, $4-5$ points are attributed to a medium dependence level, and 3 points or less mean low tobacco dependence [9]. The MNA test result of 24-30 points means a normal nutritional status, 17-23.5 points indicate the risk of malnutrition, and a result $<17$ is a sign of malnutrition [11]. Furthermore, measurements of neck circumference and body weight were carried out in order to calculate the body mass index (BMI) and waist-hip ratio (WHR) indices.

\section{Statistical analysis}

The correlations between the adopted variables were verified with the use of the $\chi^{2}$ goodness of fit test. The significance level was established at $p<0.05$.

\section{Results}

The surveyed population consisted of 126 pulmonology ward patients, with the average age within the group amounting to 57.9 years $(\mathrm{SD}=12.15)$. Men constituted the majority (58\%). Most respondents were within the 50-65-years age group (45\%). Over half of the patients came from urban areas (60\%) and had primary/basic vocational education (58\%). The patients participating in the research suffered from and were treated for lung cancer (53\%), tuberculosis (33\%), and COPD (14\%) (Table 1).

Table 2 presents the analysed risk factors of respiratory system diseases.

In the surveyed group the majority were people who smoked tobacco in the past (43\%) or were current active smokers (40\%). In the Fagerström test, the highest number of current smokers (47\%) demonstrated a medium nicotine dependence level. The majority admitted to occasional alcohol consumption (66\%). 
Over half of the respondents were at risk of malnutrition (57\%) or suffered from abdominal obesity (52\%). Other factors, such as taking tranquilisers and soporifics and previous respiratory system diseases, were less often found among the surveyed (respectively, $32 \%$ and $24 \%$ ), as well as neck circumference (22\%) and obesity (9\%) (Table 2).

Below are statistics describing tobacco smoking, results obtained with the applied research tools, and the results of measurements (Table 3).

This report is part of a lager study; below is shown the impact of selected socio-demographic characteristics on the risk factors of selected diseases in pulmonological patients. The risk factors of respiratory system diseases were significantly correlated with the respondents' sex. Men more often than women were current and past tobacco smokers $(p=0.00062)$ and more frequently reported occasional alcohol consumption ( $p=0.00814$ ) (Table 4$)$.

Age turned out to be a factor differentiating such risk factors as alcohol consumption and taking tranqui lisers and soporifics. Occasional alcohol consumption
Table 1. Characteristics of the surveyed pulmonology ward patients

\begin{tabular}{|llll|}
\hline Parameter & & $\boldsymbol{N}$ & $\%$ \\
Age [years] & Memale & 52 & 41 \\
\cline { 2 - 4 } & Male & 74 & 59 \\
\cline { 2 - 4 } Place of residence & S0-65 & 28 & 22 \\
\cline { 2 - 4 } & $>65$ & 57 & 45 \\
\cline { 2 - 4 } Education & Urban areas & 76 & 33 \\
\cline { 2 - 4 } & Rural areas & 50 & 40 \\
\cline { 2 - 4 } Respiratory system & vocational & 67 & 53 \\
\cline { 2 - 4 } disease & Secondary & 47 & 37 \\
\cline { 2 - 4 } & Higher & 12 & 10 \\
\cline { 2 - 4 } & Lung cancer & 67 & 53 \\
\cline { 2 - 4 } & COPD & 18 & 14 \\
\cline { 2 - 4 } & Tuberculosis & 41 & 33 \\
\hline
\end{tabular}

COPD - chronic obstructive pulmonary disease.

Table 2. Respiratory system diseases risk factors in the surveyed group

\begin{tabular}{|c|c|c|c|c|}
\hline \multicolumn{3}{|l|}{ Respiratory system diseases risk factors } & $N$ & $\%$ \\
\hline \multirow[t]{3}{*}{ Tobacco smoking } & \multicolumn{2}{|c|}{ Current smokers } & 51 & 40 \\
\hline & \multicolumn{2}{|c|}{ Past smokers } & 53 & 43 \\
\hline & \multicolumn{2}{|c|}{ Non-smokers } & 22 & 17 \\
\hline \multirow[t]{3}{*}{ Nicotine dependence level } & \multicolumn{2}{|l|}{ Low } & 17 & 33 \\
\hline & \multicolumn{2}{|l|}{ Medium } & 24 & 47 \\
\hline & \multicolumn{2}{|l|}{ High } & 10 & 20 \\
\hline \multirow[t]{4}{*}{ Alcohol consumption } & \multicolumn{2}{|c|}{ Non-drinkers } & 33 & 26 \\
\hline & \multirow[t]{3}{*}{ Drinkers } & Every day & 1 & 1 \\
\hline & & A few times a week & 9 & 7 \\
\hline & & Occasionally & 83 & 66 \\
\hline \multirow[t]{2}{*}{ Taking tranquilisers and soporifics } & \multicolumn{2}{|l|}{ No } & 86 & 68 \\
\hline & \multicolumn{2}{|l|}{ Yes } & 40 & 32 \\
\hline \multirow[t]{2}{*}{ Previous respiratory system diseases } & \multicolumn{2}{|l|}{ No } & 96 & 76 \\
\hline & \multicolumn{2}{|l|}{ Yes } & 30 & 24 \\
\hline \multirow[t]{3}{*}{ MNA nutrition assessment } & \multicolumn{2}{|c|}{ Normal nutritional status } & 43 & 34 \\
\hline & \multicolumn{2}{|c|}{ Risk of malnutrition } & 72 & 57 \\
\hline & \multicolumn{2}{|c|}{ Malnourished } & 11 & 9 \\
\hline \multirow[t]{4}{*}{ BMI } & \multicolumn{2}{|c|}{ Undernourishment } & 5 & 4 \\
\hline & \multicolumn{2}{|c|}{ Normal body weight } & 68 & 54 \\
\hline & \multicolumn{2}{|c|}{ Overweight } & 42 & 33 \\
\hline & \multicolumn{2}{|l|}{ Obesity } & 11 & 9 \\
\hline \multirow[t]{2}{*}{ WHR } & \multicolumn{2}{|l|}{ Normal } & 61 & 48 \\
\hline & \multicolumn{2}{|c|}{ Abnormal } & 65 & 52 \\
\hline \multirow[t]{2}{*}{ Neck circumference } & \multicolumn{2}{|l|}{ Normal } & 98 & 78 \\
\hline & \multicolumn{2}{|c|}{ Abnormal } & 28 & 22 \\
\hline
\end{tabular}

MNA - Mini Nutritional Assessment, BMI - body mass index, WHR - waist-hip ratio. 
Table 3. Statistics describing selected respiratory system diseases risk factors

\begin{tabular}{|lcccc|}
\hline Quantitative data & Average & Min. & Max. & SD \\
Cigarettes smoked daily & 13.72 & 1 & 40 & 6.85 \\
Years of active smoking & 28.28 & 8 & 50 & 11.73 \\
Fagerström test result & 4.12 & 0 & 8 & 1.63 \\
MNA & 22.15 & 13.00 & 28.00 & 3.32 \\
BMI & 24.33 & 14.42 & 34.72 & 4.03 \\
WHR & 0.95 & 0.70 & 1.64 & 0.11 \\
Neck circumference & 39.20 & 30.00 & 48.00 & 3.90 \\
\hline
\end{tabular}

MNA - Mini Nutritional Assessment, BMI - body mass index, WHR - waist-hip ratio.

was more often reported by people from the youngest age group (up to the age of 50 years) ( $p=0.00431)$, and taking tranquilisers and soporifics increased with age: the youngest group $11 \%$, the oldest $41 \%(p=0.02028)$ (Table 5). The dependence level based on the Fagerström test varied with regard to the place of residence ( $p=0.04374$ ), a high and medium dependence level concerned residents of urban areas more often than those living in rural areas (Table 6).

The research results confirm the impact of education on tobacco smoking. The majority of current smokers had secondary education, while past smokers had primary or basic vocational education
( $p=0.00082$ ). In turn, higher education was a significant differentiating factor for previous respiratory system diseases among pulmonological patients ( $p=0.01248$ ) (Table 7). More of the surveyed patients with COPD and tuberculosis than the lung cancer patients were current tobacco smokers, while among passive smokers the majority were lung cancer patients ( $p=0.00510)$ who also took tranquilisers and soporifics most frequently $(p<0.00001)$. Malnutrition more often concerned people with tuberculosis than with other diseases (Table 8).

\section{Discussion}

Literature on the subject of respiratory system diseases risk factors among patients staying on pulmonology wards focuses primarily on tobacco smoking.

The results of the authors' own research also demonstrate that tobacco smoking, both current and past, constitutes a major risk factor of respiratory system diseases. Forty percent of the surveyed patients staying on pulmonology wards were current tobacco smokers, which points to the popularity and approval of smoking in public places and in the presence of other people. Passive smoking, which, according to the Global Adult Tobacco Survey (GATS), is experienced by $44 \%$ of adult Poles at home and 34\% at the workplace, is also dangerous. As shown in the research by Malinowska-Lipien et al. [12], despite the fact that $90 \%$ of the respondents were familiar with

Table 4. Respiratory system diseases risk factors and the sex of the respondents

\begin{tabular}{|c|c|c|c|c|}
\hline Risk factors & & Female (\%) & Male (\%) & $P$-value \\
\hline \multirow[t]{3}{*}{ Tobacco smoking } & Current smokers & 29 & 47 & \multirow[t]{3}{*}{0.00062} \\
\hline & Past smokers & 38 & 46 & \\
\hline & Non-smokers & 33 & 7 & \\
\hline \multirow[t]{3}{*}{ Nicotine dependence level } & Low & 40 & 30 & \multirow[t]{3}{*}{0.43300} \\
\hline & Medium & 33 & 53 & \\
\hline & High & 27 & 17 & \\
\hline \multirow[t]{4}{*}{ Alcohol consumption } & Never & 40 & 16 & \multirow[t]{4}{*}{0.00814} \\
\hline & Every day & 0 & 1 & \\
\hline & A few times a week & 2 & 11 & \\
\hline & Occasionally & 58 & 72 & \\
\hline \multirow{2}{*}{$\begin{array}{l}\text { Taking tranquilisers } \\
\text { and soporifics }\end{array}$} & No & 67 & 69 & \multirow[t]{2}{*}{0.84830} \\
\hline & Yes & 33 & 31 & \\
\hline \multirow{2}{*}{$\begin{array}{l}\text { Previous respiratory } \\
\text { system diseases }\end{array}$} & No & 71 & 80 & \multirow[t]{2}{*}{0.26583} \\
\hline & Yes & 29 & 20 & \\
\hline \multirow[t]{3}{*}{ Nutrition level assessment } & Normal nutritional status & 36 & 32 & \multirow[t]{3}{*}{0.86530} \\
\hline & Risk of malnutrition & 56 & 58 & \\
\hline & Malnourished & 8 & 10 & \\
\hline
\end{tabular}

$p$-significance level of the $\chi^{2}$ significance test. 
Table 5. Respiratory system diseases risk factors and the age of the respondents

\begin{tabular}{|c|c|c|c|c|c|}
\hline Risk factors & & $<50(\%)$ & $50-65(\%)$ & $>65(\%)$ & $P$-value \\
\hline \multirow[t]{3}{*}{ Tobacco smoking } & Current smokers & 47 & 46 & 27 & \multirow[t]{3}{*}{0.34555} \\
\hline & Past smokers & 39 & 37 & 54 & \\
\hline & Non-smokers & 14 & 17 & 19 & \\
\hline \multirow[t]{3}{*}{ Nicotine dependence level } & Low & 54 & 18 & 46 & \multirow[t]{3}{*}{0.11316} \\
\hline & Medium & 31 & 64 & 27 & \\
\hline & High & 15 & 18 & 27 & \\
\hline \multirow[t]{4}{*}{ Alcohol consumption } & Never & 3 & 2 & 42 & \multirow[t]{4}{*}{0.00431} \\
\hline & Every day & 0 & 0 & 2 & \\
\hline & A few times a week & 18 & 5 & 2 & \\
\hline & Occasionally & 79 & 69 & 54 & \\
\hline \multirow{2}{*}{$\begin{array}{l}\text { Taking tranquilisers and } \\
\text { soporifics }\end{array}$} & No & 89 & 65 & 59 & \multirow[t]{2}{*}{0.02028} \\
\hline & Yes & 11 & 35 & 41 & \\
\hline \multirow{2}{*}{$\begin{array}{l}\text { Previous respiratory system } \\
\text { diseases }\end{array}$} & No & 79 & 68 & 85 & \multirow[t]{2}{*}{0.14321} \\
\hline & Yes & 21 & 32 & 15 & \\
\hline \multirow[t]{3}{*}{ Nutrition level assessment } & Normal nutritional status & 29 & 33 & 39 & \multirow[t]{3}{*}{0.69858} \\
\hline & Risk of malnutrition & 64 & 60 & 49 & \\
\hline & Malnourished & 7 & 7 & 12 & \\
\hline
\end{tabular}

Table 6. Respiratory system diseases risk factors and the place of residence

\begin{tabular}{|c|c|c|c|c|}
\hline Risk factors & & Urban areas (\%) & Rural areas (\%) & $P$-value \\
\hline \multirow[t]{3}{*}{ Tobacco smoking } & Current smokers & 42 & 36 & \multirow[t]{3}{*}{0.52837} \\
\hline & Past smokers & 43 & 42 & \\
\hline & Non-smokers & 15 & 22 & \\
\hline \multirow[t]{3}{*}{ Nicotine dependence level } & Low & 21 & 56 & \multirow[t]{3}{*}{0.04374} \\
\hline & Medium & 55 & 33 & \\
\hline & High & 24 & 11 & \\
\hline \multirow[t]{4}{*}{ Alcohol consumption } & Never & 21 & 34 & \multirow[t]{4}{*}{0.32684} \\
\hline & Every day & 1 & - & \\
\hline & A few times a week & 7 & 8 & \\
\hline & Occasionally & 71 & 58 & \\
\hline \multirow{2}{*}{$\begin{array}{l}\text { Taking tranquilisers and } \\
\text { soporifics }\end{array}$} & No & 71 & 64 & \multirow[t]{2}{*}{0.40538} \\
\hline & Yes & 29 & 36 & \\
\hline \multirow{2}{*}{$\begin{array}{l}\text { Previous respiratory system } \\
\text { diseases }\end{array}$} & No & 75 & 78 & \multirow[t]{2}{*}{0.69889} \\
\hline & Yes & 25 & 22 & \\
\hline \multirow[t]{3}{*}{ Nutrition level assessment } & Normal nutritional status & 33 & 36 & \multirow[t]{3}{*}{0.82629} \\
\hline & Risk of malnutrition & 59 & 54 & \\
\hline & Malnourished & 8 & 10 & \\
\hline
\end{tabular}


Table 7. Respiratory system diseases risk factors and the education level of the respondents

\begin{tabular}{|c|c|c|c|c|c|}
\hline Risk factors & & $\begin{array}{l}\text { Primary/basic } \\
\text { vocational (\%) }\end{array}$ & $\begin{array}{c}\text { Secondary } \\
(\%)\end{array}$ & $\begin{array}{l}\text { Higher } \\
(\%)\end{array}$ & $P$-value \\
\hline \multirow[t]{3}{*}{ Tobacco smoking } & Current smokers & 40 & 49 & 0 & \multirow[t]{3}{*}{0.00082} \\
\hline & Past smokers & 46 & 38 & 42 & \\
\hline & Non-smokers & 14 & 13 & 58 & \\
\hline \multirow[t]{3}{*}{ Nicotine dependence level } & Low & 41 & 25 & - & \multirow[t]{3}{*}{0.79072} \\
\hline & Medium & 44 & 50 & - & \\
\hline & High & 4 & 6 & - & \\
\hline \multirow[t]{4}{*}{ Alcohol consumption } & Never & 28 & 24 & 25 & \multirow[t]{4}{*}{0.96231} \\
\hline & Every day & 1 & 0 & 0 & \\
\hline & A few times a week & 8 & 6 & 8 & \\
\hline & Occasionally & 63 & 70 & 67 & \\
\hline \multirow{2}{*}{$\begin{array}{l}\text { Taking tranquilisers and } \\
\text { soporifics }\end{array}$} & No & 66 & 68 & 83 & \multirow[t]{2}{*}{0.48044} \\
\hline & Yes & 34 & 32 & 17 & \\
\hline \multirow{2}{*}{$\begin{array}{l}\text { Previous respiratory system } \\
\text { diseases }\end{array}$} & No & 81 & 79 & 42 & \multirow[t]{2}{*}{0.01248} \\
\hline & Yes & 19 & 21 & 58 & \\
\hline \multirow[t]{3}{*}{ Nutrition level assessment } & Normal nutritional status & 36 & 30 & 42 & \multirow[t]{3}{*}{0.71689} \\
\hline & Risk of malnutrition & 54 & 62 & 58 & \\
\hline & Malnourished & 10 & 8 & - & \\
\hline
\end{tabular}

Table 8. Risk factors among the respondents and the type of respiratory system disease

\begin{tabular}{|c|c|c|c|c|c|}
\hline Risk factors & & Lung cancer & COPD & Tuberculosis & $P$-value \\
\hline \multirow[t]{3}{*}{ Tobacco smoking } & Current smokers & 27 & 56 & 54 & \multirow[t]{3}{*}{0.00510} \\
\hline & Past smokers & 54 & 44 & 24 & \\
\hline & Non-smokers & 19 & 0 & 22 & \\
\hline \multirow[t]{3}{*}{ Nicotine dependence level } & Low & 39 & 40 & 26 & \multirow[t]{3}{*}{0.10936} \\
\hline & Medium & 61 & 30 & 44 & \\
\hline & High & - & 30 & 30 & \\
\hline \multirow[t]{4}{*}{ Alcohol consumption } & Never & 34 & 22 & 15 & \multirow[t]{4}{*}{0.08467} \\
\hline & Every day & 0 & 0 & 2 & \\
\hline & A few times a week & 3 & 6 & 15 & \\
\hline & Occasionally & 63 & 72 & 68 & \\
\hline \multirow{2}{*}{$\begin{array}{l}\text { Taking tranquilisers and } \\
\text { soporifics }\end{array}$} & No & 49 & 78 & 95 & \multirow[t]{2}{*}{$<0.00001$} \\
\hline & Yes & 51 & 22 & 5 & \\
\hline \multirow{2}{*}{$\begin{array}{l}\text { Previous respiratory system } \\
\text { diseases }\end{array}$} & No & 79 & 83 & 68 & \multirow[t]{2}{*}{0.32798} \\
\hline & Yes & 21 & 17 & 32 & \\
\hline \multirow[t]{3}{*}{ Nutrition level assessment } & Normal nutritional status & 27 & 67 & 32 & \multirow[t]{3}{*}{0.03624} \\
\hline & Risk of malnutrition & 64 & 28 & 58 & \\
\hline & Malnourished & 9 & 5 & 10 & \\
\hline
\end{tabular}


the consequences of tobacco smoking, $23 \%$ were not willing to abandon the habit. Based on the aforementioned GATS survey, in the years 2009-2010 35\% of smokers attempted to abandon the habit, while $44 \%$ did not make any such attempt [13]. It is important to mention that in the present study no current smoker had higher education. It can be assumed that the awareness of the negative consequences of smoking increases with education. The results on tobacco smoking obtained in the research are confirmed by the Report on the Health Status of Poland's Population [1] and data collected by the WHO [13], which demonstrate increased tobacco consumption among people with low education, as well as Przybylski's research [14], which shows that the majority of smokers have basic vocational education. As found in Białkowska's et al. study [15] people with basic vocational education were less willing to abandon smoking. People's attitude towards the issue depends on education, because higher education is associated with a willingness to change to healthy habits and take more interest in one's state of health [16].

The analysis of the authors' research shows that men smoke tobacco more often than women, which is confirmed also in the report by the Kujawsko-Pomorskie Pulmonology Centre in Bydgoszcz, where tobacco smoking also prevailed among men [14]. Based on the report "The health situation of Polish population and its determinants in Poland" [1] in the years $2009-2010$, 34\% of men and $21 \%$ women smoked tobacco. The number of women smoking tobacco and suffering from COPD is increasing each year, with the smoking habit being the major determinant of the disease. According to the data of the Burden of Obstructive Lung Disease (BOLD) initiative, the number of women has risen to over $2 / 3$ of COPD patients. The increasing number of women smoking tobacco can be explained by the anatomical and physiological features that differentiate them from men. Ucińska et al. [17] states that women are more prone to tobacco smoke, become addicted more easily, and have more difficulties with abandoning the habit than men.

A cancer diagnosis for most patients is associated with suffering and inevitable, painful death. The prognosis for lung cancer in Poland is one of the worst in Europe [18]. Patients with diagnosed cancer change their habits to fight for their lives. These mainly refer to quitting tobacco smoking, which is confirmed by the results of the authors' study, in which smoking was most often abandoned by lung cancer patients.

The majority of current tobacco smokers were in the surveyed group suffering from COPD (56\%) and tuberculosis (54\%). In the research by Przybylski et al. [14] analysing tobacco smoking among tuberculosis patients, $69 \%$ were smokers, while in the study by Siatkowska et al. [19] in the group of COPD patients $90 \%$ were current or past smokers. Perhaps education about the consequences of smoking as a cause of lung cancer is more effective in the case of oncological patients than those with tuberculosis and COPD. The impact of knowledge and education on the increased incidence of tuberculosis was presented by SiemionSzcześniak and Kuś [20], while patients with lower education more often suffered from TB.

Almost half (47\%) of the surveyed presented a medium level of nicotine dependence, i.e. 4.12 ( $\mathrm{SD}=1.63$ ), similarly to the research by Stokłosa et al. with the use of the same instrument, with a medium result of 5.49 $(\mathrm{SD}=2.6)$ [21]. Residents of urban areas more frequently demonstrated a medium and high tobacco dependence level, which is also confirmed by the report by Przybylski et al. [14]. Other variables did not differentiate the level of nicotine dependence, similarly to sex, age, and education in Targowski's et al. research [22]. It is assumed that the objectivity of the Fagerström test was questionable due to the fact that the surveyed were not honest about their attitudes to smoking.

In the surveyed group of pulmonological patients $74 \%$ consumed alcohol, which is a finding similar to the 2012 Report on the Health Status of Poland's Population, in which $79 \%$ of Poland's residents reported alcohol consumption within 30 days before data collection [1]. As shown in this report, men and persons below 50 years of age drink alcohol more often. It is possible that women do not admit to alcohol drinking due to the lack of social approval and stigmatisation. A decrease in alcohol consumption with patients' age was also confirmed by Bronowski et al., who assessed alcohol consumption among men staying in general hospitals [23]. Forty-five percent of the surveyed, when asked about the connection between alcohol and respiratory system diseases, replied that they did not see any correspondence. According to Wojtyniak's report, $67 \%$ of Poles do not see any connection between alcohol and cancer [1]. Drinking alcohol is conducive to smoking tobacco. In Przybylski's research a significant correlation was found between drinking and smoking among tuberculosis patients, with a much higher percentage of alcohol drinkers among smokers [14]. These findings are similar to those by Kurpas et al. [24], where alcohol consumption among students was higher in the case of those who smoked.

The problem of polypharmacy among the elderly further increases with age. This study mentions tranquilisers and soporifics, the consumption of which rises with the respondents' age. Epidemiological studies confirm that $25 \%$ of prescriptions issued for people aged more than 65 years are for soporific drugs. Prolonged consumption of benzodiazepines, which improve the quality and length of sleep, is more common among the elderly than young people [25]. As demonstrated in this study, soporifics were more often taken by lung cancer patients than those with COPD or tuberculosis. In Davidson's et al. study [26] sleeping problems most often concern oncological pa- 
tients staying in pulmonology wards, and the most common causes of insomnia are pain, discomfort, persistent thoughts, recent surgeries, and anxiety.

This study shows that people with higher education more often had a history of respiratory system diseases, which is a risk factor. This is probably not a result of previous diseases, but confirms that higher education raises awareness of such diseases and the ability to differentiate among their symptoms. However, according to the study by Bae et al. [27], a history of tuberculosis is associated with an increased risk of lung cancer among tobacco smokers.

Pulmonology patients often suffer from malnutrition. Their BMI index may point to a normal weight, which does not necessarily mean that the quality of these patients' nutrition is adjusted to their state of health. Problems with breathing and dyspnoea are associated with consuming more energy, which increases the risk of malnutrition. More than half (57\%) of the surveyed are at risk of malnutrition, which is confirmed by the average MNA result amounting to 22.15 $(\mathrm{SD}=3.32)$. In the authors' own research malnutrition and the risk of malnutrition more often concerns lung cancer and tuberculosis patients, which probably results from the specific characteristics of these diseases, which have a destructive effect on the system and contribute to a declining prognosis.

Data from NATPOL 2011 indicate that in Poland overweight or obesity occurs in $61 \%$ of men and $45 \%$ of women, and compared to previous years an increase in BMI in Poland's population has been observed [3]. The average BMI of the surveyed patients was interpreted as normal, 33\% of the respondents were overweight, and 9\% were obese. In the authors' own research the correlation between BMI and the type of disease was not analysed, but it is worth paying attention to the fact that Siatkowska et al. [19], who investigated COPD patients, found that $71 \%$ of them were overweight or obese. In turn, Posłuszna and Doboszyńska [28] claim that a low BMI is an independent determinant of morbidity and mortality in people with COPD. In the mentioned study underweight concerned $4 \%$ of all the surveyed, i.e. the same percentage as in Kuźnar-Kamińska's et al. study (4\% of COPD patients) [10].

Abdominal obesity was found in more than half of the respondents (52\%), while the average WHR result for the whole surveyed group amounted to 0.95 (SD = 0.11), which accounts for the tendency of abdominal obesity among the respondents and therefore can be regarded as a risk factor of respiratory system diseases in the surveyed population. An increased neck circumference is undoubtedly a risk factor of obstructive respiratory diseases. The average measurement result of 39.20 ( $\mathrm{SD}=3.90$ ) does not point to any irregularities. An abnormal neck circumference was observed in $22 \%$ of the surveyed. According to Pływaczewski’s study [29], in men the neck circumference value is higher and equals $46 \pm 3.4 \mathrm{~cm}$, and, moreover, patients with obesity and abnormal neck circumference were more often diagnosed with obstructive sleep apnoea. Similarly, in the study by Kang et al. [30] a crucial influence of increased anthropometric indicators (neck circumference and BMI) on the occurrence of obstructive sleep apnoea has been proven. In a metaanalysis by Cho et al. [31], only neck circumference was strongly associated with obstructive sleep apnoea, and no influence of BMI, waist circumference, or ratio of waist and hip was proven.

The prevention of respiratory system diseases should be based on the knowledge of risk factors, with tobacco smoking as the most important among them. It is also crucial to draw attention to such factors as alcohol abuse, and also improper nutrition and its consequences. Minimising or eliminating these factors will make it possible to develop healthy habits that can contribute to slowing the progression of the disease or preventing it [32].

\section{Conclusions}

The most frequent risk factor for respiratory system diseases is tobacco smoking, the risk of malnutrition, and abdominal obesity. Tobacco smoking is more often practised by men, people with lower education, and COPD and tuberculosis patients. The risk of malnutrition is associated with tuberculosis and lung cancer. Tobacco consumption as a risk factor of respiratory system diseases more often applies to men and people below the age of 50 years. The use of soporific drugs increases with age and concerns lung cancer patients. Earlier respiratory system diseases are significantly correlated with the respondents' lower education.

\section{Conflict of interest}

The authors declare no conflict of interest.

\section{References}

1. Wojtyniak B, Goryński P, Moskalewicz B (eds). Sytuacja zdrowotna ludności Polski i jej uwarunkowania. Narodowy Instytut Zdrowia Publicznego - PZH, Warszawa 2012.

2. Dunga JA, Adamu Y, Kida IM, Alasiya D, Jibrin Y, Sabo U, Ukoli C, Chuhwak CH, Musa JJ. Tobacco abuse and its health effect. Niger J Med 2015; 24: 354-62.

3. Zdrojewski T, Bandosz P, Gaciong Z, Wyrzykowski B w imieniu Komitetu Naukowego Programu NATPOL 2011. Rozpowszechnienie czynników ryzyka chorób układu sercowo-naczyniowego w Polsce w 2011 r. Zakres wieku 18-79 lat. XV Międzynarodowy Kongres Polskiego Towarzystwa Kardiologicznego. Wrocław 6-8 października 2011.

4. Volkmann T, Moonan PK, Miramontes R, Oeltmann JE. Tuberculosis and excess alcohol use in the United States, 1997-2012. Int J Tuberc Lung Dis 2015; 19: 111-9.

5. Kaphalia L, Kalita M, Kaphalia BS, Calhoun WJ. Effects of acute ethanol exposure on cytokine production by pri- 
mary airway smooth muscle cells. Toxicol Appl Pharmacol 2016; 292: 85-93.

6. Traphagen N, Tian Z, Allen-Gipson D. Chronic ethanol exposure: pathogenesis of pulmonary disease and dysfunction. Biomolecules 2015; 5: 2840-53.

7. Kittivoravitkul P, Kaw R, Hatipoğlu U, Wang L, Aboussouan LS. Determinants of wake Pco2 and increases in wake Pco2 over time in patients with obstructive sleep apnea. Ann Am Thorac Soc 2016; 13: 259-64.

8. Wysocki J, Charuta A, Kowalcze K, Ptaszyńska-Sarosiek I. Anthropometric and physiologic assessment in sleep apnoea patients regarding body fat distribution. Folia Morphol 2016; 75: 393-9.

9. Hayden LP, Hobbs BD, Cohen RT, Wise RA, Checkley W, Crapo JD, Hersh CP; COPDGene Investigators. COPD Gene Investigators. Childhood pneumonia increases risk for chronic obstructive pulmonary disease: the COPD Gene study. Respir Res 2015; 16: 115.

10. Kuźnar-Kamińska B, Batura-Gabryel H, Brajer B, Kamiński J. Analiza zaburzeń stanu odżywienia u pacjentów z przewlekłą obturacyjną chorobą płuc. Pneumon Alergol Pol 2008; 76: 327-33.

11. Kostka T, Koziarska-Rościszewska M. Choroby wieku podeszłego. PZWL, Warszawa 2009.

12. Malinowska-Lipień I, Starzec G, Gabryś T, Brzostek T, Kawalec E, Reczek A, Gawor A. Poziom wiedzy pacjentów z przewlekłą obturacyjną chorobą płuc na temat wpływu nikotynizmu na rozwój choroby. Wyniki wstępne. Probl Pielęg 2007; 15: 39-43.

13. WHO. Global Adult Tobacco Survey (GATS). Poland 2009-2010.

14. Przybylski G, Dąbrowska A, Gołda R, Gadzińska A, Trzcinska H. Analiza palenia tytoniu wśród chorych na gruźlicę - dane z dziesięciu lat obserwacji z Kujawsko-Pomorskiego Centrum Pulmonologii w Bydgoszczy. Prz Lek 2012; 69: 953-7.

15. Białkowska J, Mroczkowska D, Szypulska A, Fischer B. Ocena świadomości chorych palących papierosy na temat wpływu palenia tytoniu na występowanie chorób cywilizacyjnych. Med Środow 2013; 16: 23-30.

16. Szwed A. Ocena stopnia motywacji i uzależnienia od nikotyny u palaczy podejmujących próbę zerwania z nałogiem. Pneumonol Alergol Pol 2012; 80: 516-22.

17. Ucińska R, Damps-Konstańska I, Siemińska A, Jassem E. Przewlekła obturacyjna choroba płuc u kobiet. Pneumonol Alergol Pol 2012; 80: 140-5.

18. Kosacka M, Jankowska R. Epidemiologia raka płuc. Pneumonol Alergol Pol 2007; 75: 76-80.

19. Siatkowska H, Jastrzębski D, Kozielski J. Palenie papierosów a objawy kliniczne, czynność układu oddechowego i choroby towarzyszace. Pol Merkuriusz Lek 2010; 29: 8-13.

20. Siemion-Szcześniak I, Kuś J. Wpływ czynników społecznych na wyniki leczenia chorych na gruźlicę płuc potwierdzoną bakteriologicznie. Pneumonol Alergol Pol 2012; 80: 412-21.

21. Stokłosa A, Skoczylas A, Rudnicka A, Bednarek M, Krzyżanowski K, Górecka D. Ocena motywacji do rzucenia palenia u pacjentów poradni antynikotynowej. Pneumonol Alergol Pol 2010; 78: 211-5.

22. Targowski T, From S, Rożyńska R, Mierzejewska J. Wpływ niektórych czynników demograficznych i socjalnych na stopień uzależnienia od nikotyny oraz motywację do rzucenia palenia tytoniu u zdrowych. Pneumonol Alergol Pol 2004; 72: 198-200.
23. Bronowski P, Sawicka M, Kluczyńska S. Rozpowszechnienie spożycia alkoholu wśród pacjentów szpitali ogólnych po 60 roku życia. Gerontol Pol 2011; 19: 47-52.

24. Kurpas D, Mroczek B, Bielska D, Wojtal M, Seń M, Steciwko A. Spożycie alkoholu i palenie tytoniu wśród studentów wyższych uczelni medycznych. Prz Lek 2012; 69: 893-5.

25. Sobów T. Benzodiazepiny u pacjentów w wieku podeszłym. Psychiatry 2010; 7: 244-9.

26. Davidson JR, MacLean AW, Brundage MD, Schulze K. Sleep disturbance in cancer patients. Soc Sci Med 2002; 54: 1309-21.

27. Bae JM, Li ZM, Shin MH, Kim DH, Lee MS, Ahn YO. Pulmonary tuberculosis and lung cancer risk in current smokers: the Seoul male cancer cohort study. J Korean Med Sci 2013; 28: 896-900.

28. Posłuszna D, Doboszyńska A. Ocena stanu odżywienia u chorych na przewlekłą obturacyjną chorobę płuc (POChP) oraz wpływ diety na ryzyko jej wystąpienia. Pneumonol Alergol Pol 2011; 79: 109-15.

29. Pływaczewski R, Bieleń P, Bednarek M, Jonczak L, Górecka D, Śliwiński P. Wpływ obwodu szyi i wskaźnika masy ciała na zaawansowanie obturacyjnego bezdechu sennego u mężczyzn. Pneumonol Alergol Pol 2008; 76: 313-20.

30. Kang HH, Kang JY, Ha JH, Lee J, Kim SK, Moon HS, Lee SH. The associations between anthropometric indices and obstructive sleep apnea in a Korean population. PLoS One 2014; 9: e114463.

31. Cho JH, Choi JH, Suh JD, Ryu S, Cho SH. Comparison of anthropometric data between Asian and Caucasian patients with obstructive sleep apnea: a meta-analysis. Clin Exp Otorhinolaryngol 2016; 9: 1-7.

32. Majda A, Józefowska H. Zasoby osobiste pacjentów z przewlekłą obturacyjną chorobą płuc. Probl Pielęg 2009; 17: 283-93.

\section{Address for correspondence:}

Agnieszka B. Bartoszek MD, PhD

Department of Family Medicine and Community Nursing

Chair of Oncology and Environmental Health

Faculty of Health Science

Medical University of Lublin

ul. S. Staszica 4-6, 20-081 Lublin, Poland

Phone: +48 660111697

E-mail: agabartoszek@wp.pl 